J. Pijar MIPA, Vol. III No.1, Maret 2008 : 17 - 22.

ISSN 1907-1744

\title{
MODEL PEMBELAJARAN TERPADU UNTUK SAINS
}

\author{
Kesipudin dan Hikmawati \\ Program studi Pendidikan Fisika FKIP Unram \\ Jl. Majapahit No. 62 Mataram 83125
}

\begin{abstract}
Abstrak. Model pembelajaran terpadu merupakan salah satu model implementasi kurikulum yang dianjurkan untuk diaplikasikan pada semua jenjang pendidikan, mulai dari tingkat Sekolah Dasar/Madrasah Ibtidaiyah (SD/MI) sampai dengan Sekolah Menengah Atas/Madrasah Aliyah (SMA/MA). Model pembelajaran ini pada hakikatnya merupakan suatu pendekatan pembelajaran yang memungkinkan peserta didik baik secara individual maupun kelompok aktif mencari, menggali, dan menemukan konsep serta prinsip secara holistik dan otentik. Pembelajaran terpadu dalam sains dapat dikemas dengan tema atau topik tentang suatu wacana yang dibahas dari berbagai sudut pandang atau disiplin keilmuan yang mudah dipahami dan dikenal peserta didik. Dalam pembelajaran sains terpadu, suatu konsep atau tema dibahas dari berbagai aspek mata pelajaran dalam bidang kajian sains. Tema lingkungan dapat dibahas dari sudut biologi, fisika, dan kimia. Dengan demikian melalui pembelajaran terpadu ini beberapa konsep yang relevan untuk dijadikan tema tidak perlu dibahas berulang kali dalam mata pelajaran yang berbeda, sehingga penggunaan waktu untuk pembahasannya lebih efisien dan pencapaian tujuan pembelajaran juga diharapkan akan lebih efektif.
\end{abstract}

Kata-kata kunci: Model pembelajaran terpadu, sains.

\section{INTEGRATED LEARNING MODEL FOR SCIENCE}

\begin{abstract}
Integrated learning model is one of the curriculum implementations which is recommended to be applied in all levels of education beginning from elementary schools (SD/MI) up to senior high schools. This type of teaching model is basically an approach which possibly makes students, either individually or in groups, actively find out concept and principle holistically and authentically. Integrated teaching in science can be design with theme or topic about discourse which can be discussed from various points of view or disciplines which are easily understood by the students. Environment theme, can be discussed from biological, physical and chemistry points of view. Thus, through integrated teaching, other relevant concepts are not necessary to be discussed again in different subjects so that it saves time, and the teaching objective can be reached more effectively.

Key words: Integrated learning model, science.
\end{abstract}

\section{PENDAHULUAN}

Secara umum sains di Sekolah Menengah, meliputi mata pelajaran fisika, bumi antariksa, biologi, dan kimia yang sebenarnya sangat berperan dalam membantu anak untuk memahami fenomena alam. Sains merupakan pengetahuan ilmiah, yaitu pengetahuan yang telah mengalami uji kebenaran melalui metode ilmiah, dengan ciri: objektif, metodik, sistematis, universal, dan tentatif. sains merupakan ilmu yang pokok bahasannya adalah alam dengan segala isinya.

Pada dasarnya, hakikat sains meliputi empat unsur utama, yaitu

1) Sikap: rasa ingin tahu tentang benda, fenomena alam, mahluk hidup, serta hubungan sebab akibat yang menimbulkan masalah baru yang dapat dipecahkan melalui prosedur yang benar.
2) Proses: prosedur pemecahan masalah melalui metode ilmiah yang meliputi penyusunan hipotesis, perancangan eksperimen atau percobaan, evaluasi, pengukuran, dan penarikan kesimpulan.

3) Produk: berupa fakta, prinsip, teori, dan hukum.

4) Aplikasi: penerapan metode ilmiah dan konsep sains dalam kehidupan sehari- hari.

Keempat unsur itu merupakan ciri sains yang utuh yang sebenarnya tidak dapat dipisahkan satu dengan yang lain.

Dalam proses pembelajaran sains keempat unsur itu diharapkan dapat muncul, sehingga peserta didik dapat mengalami proses pembelajaran secara utuh, memahami fenomena alam melalui kegiatan pemecahan masalah, metode ilmiah, dan meniru cara ilmuwan bekerja dalam menemukan fakta baru. Kecenderungan pembelajaran sains pada masa kini adalah peserta didik hanya mempelajari sains 
sebagai produk, menghafalkan konsep, teori dan hukum. Keadaan ini diperparah oleh pembelajaran yang berorientasi pada tes/ujian. Akibatnya sains sebagai proses, sikap, dan aplikasi tidak tersentuh dalam pembelajaran.

Pengalaman belajar yang diperoleh di kelas tidak utuh dan tidak berorientasi pada tercapainya standar kompetensi dan kompetensi dasar. Pembelajaran lebih bersifat teachercentered, guru hanya menyampaikan sains sebagai produk dan peserta didik menghafal informasi faktual. Peserta didik hanya mempelajari sains pada domain kognitif yang terendah. Peserta didik tidak dibiasakan untuk mengembangkan potensi berpikirnya. Fakta di lapangan menunjukkan bahwa banyak peserta didik yang cenderung menjadi malas berpikir secara mandiri. Cara berpikir yang dikembangkan dalam kegiatan belajar belum menyentuh domain afektif dan psikomotor. Alasan yang sering dikemukakan oleh para guru adalah keterbatasan waktu, sarana, lingkungan belajar, dan jumlah peserta didik per kelas yang terlalu banyak.

Untuk mencapai tujuan pendidikan sains di sekolah menengah harus diberikan secara terpadu dalam artian bahwa alam sekitar peserta didik perlu diperkenalkan sebagai suatu keutuhan lingkungan di mana mereka berada atau guru dapat mengaitkan satu pokok bahasan satu dengan pokok bahasan berikutnya, mengaitkan satu konsep satu dengan konsep yang lain, mengaitkan satu keterampilan dengan keterampilan lain, dan dapat juga mengaitkan satu pekerjaan hari itu dengan hari lain atau hari berikutnya [3].

Menurut Druxes dkk. [1] berdasarkan alasan-alasan didaktik dianjurkan sains di sekolah diajarkan secara terpadu. Belum ditemukan alasan yang kuat berdasarkan didaktik memisahkan sains secara terpisah. Menurut sejarah sains bahwa pemisahan menjadi fisika, biologi, kimia dan seterusnya tidak terjadi karena alasan prinsip, melainkan atas dasar pengkhususan (spesialisasi). Bukankah alam dan ilmu pengetahuan mengenai alam itu sebenarnya merupakan suatu keutuhan, satu paduan?

Meminjam bahasanya Bentley dan Watts bahwa Pengajaran sains dikembangkan berdasarkan persoalan atau tema sains untuk dapat dikaji dari aspek kemampuan peserta didik yang mencakup aspek mengkomunikasikan konsep secara ilmiah, aspek pengembangan konsep dasar sains, dan pengembangan kesadaran sains dalam konteks ekonomi dan sosial. Konsep pembelajaran sains tersebut berarti mengandung seluruh aspek yang berhubungan dengan pengetahuan untuk dapat menanggapi isu lokal, nasional, kawasan, dunia, sosial, ekonomi, lingkungan dan etika, serta menilai secara kritis perkembangan dalam bidang sains dan teknologi serta dampaknya [6].

Abad 21, ditandai oleh pesatnya perkembangan sains dan teknologi dalam berbagai bidang kehidupan di masyarakat, terutama teknologi informasi dan komunikasi. Oleh karena itu, diperlukan cara pembelajaran yang dapat menyiapkan peserta didik untuk melek sains dan teknologi, mampu berpikir logis, kritis, kreatif, serta dapat berargumentasi secara benar. Dalam kenyataan, memang tidak banyak peserta didik yang menyukai mata pelajaran sains, karena dianggap sukar, keterbatasan kemampuan peserta didik, atau karena mereka tak berminat menjadi ilmuwan atau ahli teknologi. Namun demikian, mereka tetap berharap agar pembelajaran sains di sekolah dapat disajikan secara menarik, efisien, dan efektif.

Standar Kompetensi dan Kompetensi Dasar yang akan dicapai peserta didik yang dituangkan dalam empat aspek yaitu makhluk hidup dan proses kehidupan, materi dan sifatnya, energi dan perubahannya, serta bumi dan alam semesta. Indikator pencapaian kompetensi dikembangkan oleh sekolah, disesuaikan dengan lingkungan setempat, dan media serta lingkungan belajar yang ada di sekolah. Semua ini ditujukan agar guru dapat lebih aktif, kreatif, dan melakukan inovasi dalam pembelajaran tanpa meninggalkan isi kurikulum.

Agar peserta didik dapat mempelajari sains dengan benar, maka sains harus dikenalkan secara utuh, baik menyangkut objek, persoalan, maupun tingkat organisasi dari benda-benda yang ada di dalam alam semesta. Dengan begitu agar peserta didik dapat mengenal kebulatan sains sebagai ilmu, maka seluruh tema dan persoalan sains pada berbagai jenis objek dan tingkat organisasinya hendaknya kajiannya luas memenuhi keutuhannya. Dengan kata lain bahwa sains sebagai mata pelajaran di sekolah hendaknya diajarkan secara utuh atau terpadu, tidak dipisah-pisahkan antara biologi, fisika, kimia dan bumi antariksa.

Keunggulan pembelajaran terpadu yaitu: (a) pengalaman dan kegiatan belajar anak relevan dengan tingkat perkemangannya, (b) kegiatan yang dipilih sesuai dengan minat dan kebutuhan siswa, (c) kegiatan belajar bermakna bagi anak sehingga hasilnya dapat bertahan lama, (d) keterampilan berpikir anak berkembang dalam proses pembelajaran terpadu, (e) kegiatan belajar mengajar bersifat pragmatis sesuai dengan lingkungan anak, dan (f) keterampilan sosial anak berkembang dalam proses pembelajaran terpadu seperti kerjasama, komunikasi, dan mau mendengarkan pendapat orang lain [4].

Melalui pembelajaran sains terpadu, diharapkan peserta didik dapat membangun pengetahuannya melalui cara kerja ilmiah, bekerja sama dalam kelompok, belajar berinteraksi dan berkomunikasi, serta bersikap ilmiah.

\section{PEMBAHASAN}

Landasan filosofis pembelajaran sains terpadu ialah filsafat pendidikan Progresivisme yang dikembangkan oleh para ahli pendidikan seperti John Dewey, William Kilpatrick, George Count, dan Harold Rugg diawal abad 20. Progresvisme merupakan pendidikan yang berpusat pada siswa dan memberi penekanan lebih besar pada kreativitas, aktivitas, belajar "naturalistik", hasil belajar "dunia nyata" dan juga pengalaman teman sebaya. Pembelajaran sains terpadu merupakan konsep pembelajaran sains dengan situasi lebih alami dan situasi dunia nyata, serta mendorong siswa membuat hubungan antar cabang sains dan antara pengetahuan yang dimilikinya dengan penerapannya dalam kehidupan sehari hari [6].

Pembelajaran sains terpadu merupakan pembelajaran bermakna yang memungkinkan siswa menerapkan konsepkonsep sains dan berpikir tingkat tinggi dan memungkinkan mendorong siswa peduli dan tanggap terhadap lingkungan dan budayanya. Dalam pembelajaran sains hendaknya guru dapat merancang dan mempersiapkan suatu pembelajaran dengan memotivasi awal sehingga dapat menimbulkan suatu 
pertanyaan. Dengan begitu, guru yang bertugas dapat mendorong, membimbing dan menilai kemampuan berpikir siswa dalam melaksanakan pembelajaran berdasarkan inkuiri. Ciri utama pembelajaran sains adalah dimulai dengan pertanyaan atau masalah dilanjutkan dengan arahan guru menggali informasi, mengkonfirmasikan dengan pengetahuan yang sudah dimiliki dan mengarahkan pada tujuan apa yang belum dan harus diketahui. Jadi terlihat bahwa siswa akan dapat menemukan sendiri jawaban dari masalah atau pertanyaan yang timbul diawal pembelajaran. Pengetahuan dan keterampilan yang diperoleh diharapkan tidak dengan jalan mengingat seperangkat fakta-fakta, tetapi dengan jalan menemukan dan menggeneralisasi sendiri sebagai hasil kemandiriannya.

Dengan begitu, untuk pembelajaran sains hendaknya dilakukan dalam kelompok-kelompok kecil yang anggotanya heterogen, untuk dapat bekerja sama, saling berinteraksi dan mendiskusikan hasil secara bersama-sama, saling menghargai pendapat teman, sampai dapat memutuskan kesimpulan yang disepakati bersama. Menurut Prabowo [4] pembelajaran terpadu adalah suatu proses pembelajaran dengan melibatkan/mengkaitkan berbagai bidang studi. Dalam pembelajaran terpadu terdapat keterkaitan antardisiplin ilmu dan interdisiplin ilmu. Ketika suatu tema/ konsep dikaitkan dengan tema-tema/konsep lain yang masih dalam satu disiplin ilmu disebut dengan keterkaitan interdisiplin. Ketika suatu tema/konsep dalam suatu mata pelajaran dikaitkan dengan tema/konsep dari mata pelajaran lain maka disebut dengan keterkaitan antar disiplin ilmu.

Secara umum di dalam pembelajaran terpadu dikenal tiga cara pengintegrasian kurikulum yakni pengintegrasian di dalam satu disiplin ilmu, pengintegrasian beberapa disiplin ilmu, dan pengintegrasian di dalam dan beberapa disiplin ilmu [2]. Beberapa model pembelajaran yang sesuai untuk diterapkan dalam pembelajaran antara lain adalah: model pembelajaran langsung, model pembelajaran kooperatif, model pembelajaran berdasarkan masalah, dan sebagainya.

Sains berkaitan dengan cara mencari tahu tentang alam secara sistematis, sehingga sains bukan hanya terbatas pada penguasaan kumpulan pengetahuan yang berupa fakta-fakta, konsep-konsep, atau prinsip-prinsip saja melainkan juga merupakan suatu proses penemuan. Pendidikan sains diharapkan dapat menjadi wahana bagi peserta didik untuk mempelajari diri sendiri dan alam sekitar, serta prospek pengembangan lebih lanjut dalam menerapkannya pada kehidupan sehari-hari. Proses pembelajarannya menekankan pada pemberian pengalaman langsung untuk mengembangkan kompetensi agar menjelajahi dan memahami alam sekitar secara ilmiah. Pendidikan sains diarahkan untuk inkuiri dan berbuat sehingga dapat membantu peserta didik untuk memperoleh pemahaman yang lebih mendalam tentang alam sekitar.

\subsection{Tujuan Pembelajaran Sains Terpadu}

\subsubsection{Meningkatkan efisiensi dan efektivitas pembelajaran}

Dalam Standar Kompetensi dan Kompetensi Dasar yang harus dicapai peserta didik masih dalam lingkup disiplin ilmu fisika, kimia, dan biologi. Banyak ahli yang menyatakan pembelajaran sains yang disajikan secara disiplin keilmuan dianggap terlalu dini bagi anak usia 7-14 tahun, karena anak pada usia ini masih dalam transisi dari tingkat berpikir operasional konkret ke tingkat berpikir abstrak. Lagi pula, anak melihat dunia sekitarnya masih secara holistik. Atas dasar itu, maka pembelajaran sains hendaknya disajikan dalam bentuk yang utuh dan tidak parsial. Pembelajaran yang disajikan terpisah-pisah dalam fisika, biologi, kimia, dan bumi-alam semesta memungkinkan adanya tumpang tindih dan pengulangan, sehingga membutuhkan waktu dan energi yang lebih banyak, serta membosankan bagi peserta didik. Bila terdapat konsep yang tumpang tindih dan pengulangan maka dapat dipadukan, sehingga proses pembelajaran dapat berjalan lebih efisien dan efektif.

Dalam strategi pembelajaran model terpadu ini, seorang guru dituntut memiliki kepiawaian untuk memahami secara detail dan terurai terhadap konsep-konsep yang berserakan tersebut sehingga menjadi konsep yang utuh. Guru perlu menarik benang merah atau menangkap galur-galur gagasan tentang suatu konsep yang terdapat dalam berbagai disiplin ilmu (mata pelajaran). Galur-galur tersebut kemudian disimpulkan secara rinci dari khusus ke umum sehingga menjadi konsep (pengetahuan, pemahaman) yang utuh dan menyeluruh [5].

Model keterpaduan mata pelajaran dapat mendorong guru untuk mengembangkan kreativitas tinggi karena adanya tuntutan untuk memahami keterkaitan antara satu materi dengan materi yang lain. Guru juga dituntut memiliki kecermatan, kemampuan analitik, dan kemampuan kategorik agar dapat memahami keterkaitan atau kesamaan materi maupun metodologi.

\subsubsection{Meningkatkan minat dan motivasi}

Pembelajaran terpadu pada sains dapat memberikan peluang bagi guru untuk mengembangkan situasi pembelajaan yang utuh, menyeluruh, dinamis, dan bermakna sesuai dengan harapan dan kemampuan guru, serta kebutuhan dan kesiapan peserta didik. Dalam hal ini, pembelajaran terpadu memberikan peluang bagi pengembangan ilmu pengetahuan yang berkaitan dengan tema yang disampaikan.

Penggunaan strategi pembelajaran model ini secara metodologis dapat mengembangkan kemampuan dan kreativitas siswa secara lebih efektif karena pendekatan ini menuntun siswa untuk membuka wawasan dan cara berpikir yang luas dan mendalam melalui pemahaman terhadap konsep secara lintas disiplin ilmu [5].

Pembelajaran sains terpadu dapat mempermudah dan memotivasi peserta didik untuk mengenal, menerima, menyerap, dan memahami keterkaitan atau hubungan antara konsep pengetahuan dan nilai atau tindakan yang termuat dalam tema tersebut. Dengan model pembelajaran yang terpadu dan sesuai dengan kehidupan sehari-hari, peserta didik digiring untuk berpikir luas dan mendalam untuk menangkap dan memahami hubungan konseptual yang disajikan guru. Selanjutnya peserta didik akan terbiasa berpikir terarah, teratur, utuh, menyeluruh, sistemik, dan analitik. Peserta didik akan lebih termotivasi dalam belajar bila mereka merasa bahwa pembelajaran itu bermakna baginya, dan bila mereka berhasil menerapkan apa yang telah dipelajarinya. 


\subsubsection{Beberapa kompetensi dasar dapat dicapai sekaligus}

Model pembelajaran sains terpadu dapat menghemat waktu, tenaga, dan sarana, serta biaya karena pembelajaran beberapa kompetensi dasar dapat diajarkan sekaligus. Pembelajaran terpadu juga menyederhanakan langkahlangkah pembelajaran. Hal ini terjadi karena adanya proses pemaduan dan penyatuan sejumlah standar kompetensi, kompetensi dasar, dan langkah pembelajaran yang dpanndang memiliki kesamaan atau keterkaitan.

\subsection{Karakteristik Mata Pelajaran Sains}

Karateristik mata pelajaran sains di Sekolah Menengah antara lain sebagai berikut:

1. sains merupakan gabungan dari unsur-unsur fisika, kimia, biologi, serta bumi dan antariksa.

2. Kompetensi Dasar sains berasal dari struktur keilmuan fisika, kimia, biologi, serta bumi dan antariksa yang dikemas sedemikian rupa sehingga menjadi pokok bahasan atau topik (tema) tertentu.

3. Kompetensi Dasar sains juga menyangkut berbagai masalah yang dirumuskan dengan pendekatan interdisipliner dan multidisipliner.

\subsection{Konsep Pembelajaran Terpadu Dalam Sains}

\subsubsection{Kekuatan dan Kelemahan Pembelajaran Terpadu}

Walaupun standar kompetensi dan kompetensi dasar sains dikembangkan dalam sub mata pelajaran, pada tingkat pelaksanaan guru memiliki keleluasaan dalam membelajarkan peserta didiknya untuk mencapai kompetensi tersebut. Salah satu contoh yang akan dikembangkan dalam model ini adalah guru dapat mengidentifikasi standar kompetensi dan kompetensi dasar yang dekat dan relevan untuk dikemas dalam satu tema dan disajikan dalam kegiatan pembelajaran yang terpadu. Yang perlu dicatat ialah pemaduan kegiatan dalam bentuk tema sebaiknya dilakukan pada jenjang kelas yang sama dan masih dalam lingkup sains.

Kekuatan/manfaat yang dapat dipetik melalui pelaksanaan pembelajaran terpadu antara lain sebagai berikut:

1. Dengan menggabungkan berbagai mata pelajaran akan terjadi penghematan waktu, karena ketiga disiplin ilmu (Fisika, Kimia, dan Biologi) dapat diajarkan sekaligus. Tumpang tindih materi juga dapat dikurangi bahkan dihilangkan.

2. Peserta didik dapat melihat hubungan yang bermakna antar konsep Fisika, Kimia, dan Biologi.

3. Meningkatkan taraf kecakapan berpikir peserta didik, karena peserta didik dihadapkan pada gagasan atau pemikiran yang lebih luas dan lebih dalam ketika menghadapi situasi pembelajaran.

4.Pembelajaran terpadu menyajikan penerapan/aplikasi tentang dunia nyata yang dialami dalam kehidupan sehari-hari, sehingga memudahkan pemahaman konsep dan kepemilikan kompetensi sains.

5. Motivasi belajar peserta didik dapat diperbaiki dan ditingkatkan.
6. Pembelajaran terpadu membantu menciptakan struktur kognitif yang dapat menjembatani antara pengetahuan awal peserta didik dengan pengalaman belajar yang terkait, sehingga pemahaman menjadi lebih terorganisir dan mendalam, sehingga memudahkan memahami hubungan materi sains dari satu konteks ke konteks lainnya.

7. Akan terjadi peningkatan kerja sama antarguru submata pelajaran terkait, guru dengan peserta didik, peserta didik dengan peserta didik, peserta didik/guru dengan narasumber; sehingga belajar lebih menyenangkan, belajar dalam situasi nyata, dan dalam konteks yang lebih bermakna.

Kekuatan/manfaat yang dikemukakan itu, model pembelajaran sains Terpadu juga memiliki kelemahan. Perlu disadari, bahwa sebenarnya tidak ada model pembelajaran yang cocok untuk semua konsep, oleh karena itu model pembelajaran harus disesuaikan dengan konsep yang akan diajarkan.

Begitu pula dengan pembelajaran terpadu dalam sains memiliki beberapa kelemahan sebagai berikut ini:

a. Aspek Guru: Guru harus berwawasan luas, memiliki kreativitas tinggi, keterampilan metodologis yang handal, rasa percaya diri yang tinggi, dan berani mengemas dan mengembangkan materi. Secara akademik, guru dituntut untuk terus menggali informasi ilmu pengetahuan yang berkaitan dengan materi yang akan diajarkan dan banyak membaca buku agar penguasaan bahan ajar tidak terfokus pada mata pelajaran tertentu saja. Tanpa kondisi ini, maka pembelajaran terpadu dalam sains akan sulit terwujud.

b. Aspek peserta didik: Pembelajaran terpadu menuntut kemampuan belajar peserta didik yang relatif "baik", baik dalam kemampuan akademik maupun kreativitasnya. Hal ini terjadi karena model pembelajaran terpadu menekankan pada kemampuan analitik (mengurai), kemampuan asosiatif (menghubunghubungkan), kemampuan eksploratif dan elaboratif (menemukan dan menggali). Bila kondisi ini tidak dimiliki, maka penerapan model pembelajaran terpadu ini sangat sulit dilaksanakan.

c. Aspek sarana dan sumber pembelajaran: Pembelajaran terpadu memerlukan bahan bacaan atau sumber informasi yang cukup banyak dan bervariasi, mungkin juga fasilitas internet. Semua ini akan menunjang, memperkaya, dan mempermudah pengembangan wawasan. Bila sarana ini tidak dipenuhi, maka penerapan pembelajaran terpadu juga akan terhambat.

d. Aspek kurikulum: Kurikulum harus luwes, berorientasi pada pencapaian ketuntasan pemahaman peserta didik (bukan pada pencapaian target penyampaian materi). Guru perlu diberi kewenangan dalam mengembangkan materi, metode, penilaian keberhasilan pembelajaran peserta didik.

e. Aspek penilaian: Pembelajaran terpadu membutuhkan cara penilaian yang menyeluruh (komprehensif), yaitu menetapkan keberhasilan belajar peserta didik dari beberapa mata pelajaran terkait yang dipadukan. Dalam kaitan ini, guru selain dituntut untuk menyediakan teknik dan prosedur pelaksanaan penilaian dan 


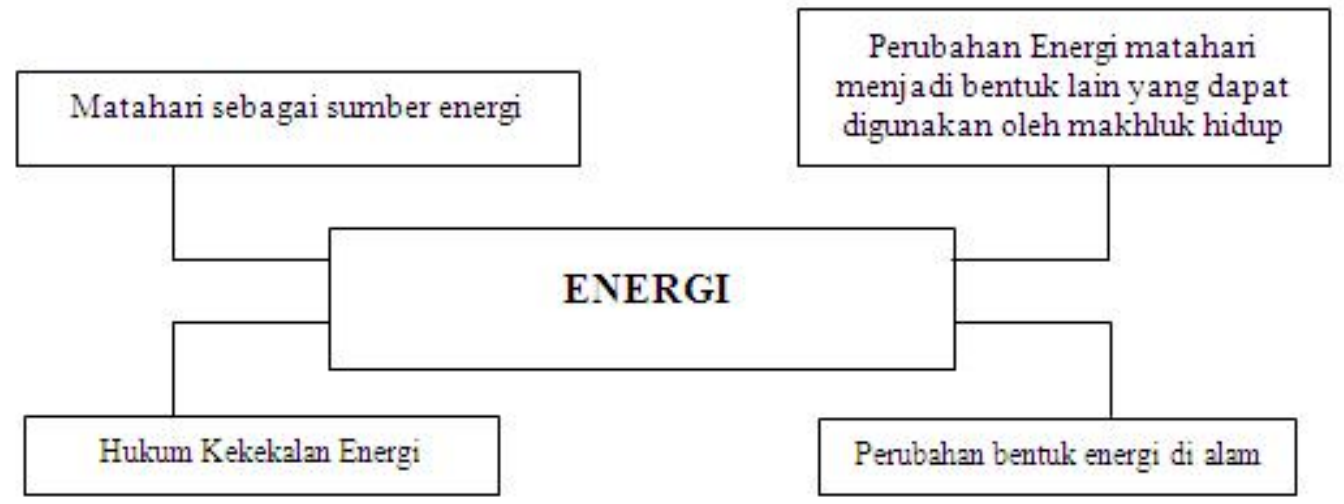

\section{Gambar 1. Jaringan Tema Energi}

pengukuran yang komprehensif, juga dituntut untuk berkoordinasi dengan guru lain, bila materi pelajaran berasal dari guru yang berbeda.

f. Suasana pembelajaran: Pembelajaran terpadu cenderung mengutamakan salah satu mata pelajaran dan menenggelamkan mata pelajaran lain. Dengan kata lain, pada saat mengajarkan sebuah tema, maka guru cenderung menekankan atau mengutamakan substansi gabungan tersebut sesuai dengan pemahaman, selera, dan latar belakang pendidikan guru itu sendiri.

Sekalipun pembelajaran terpadu mengandung beberapa kelemahan disamping keunggulannya, sebagai sebuah bentuk inovasi dalam implementasi Standar Kompetensi dan Kompetensi Dasar perlu dikembangkan lebih lanjut. Untuk konsep-konsep dari berbagai sub mata pelajaran. Pengertian terpadu di sini mengandung makna menghubungkan sains dengan berbagai mata pelajaran. Lintas sub mata pelajaran dalam sains adalah mengkoordinasikan berbagai disiplin ilmu seperti biologi, fisika, kimia, geologi, dan astronomi. Sebenarnya sains dapat juga dipadukan dengan mata pelajaran lain di luar bidang kajian sains dan hal ini lebih sesuai untuk jenjang pendidikan Sekolah Dasar. Mengingat pembahasan materi sains pada tingkat lebih tinggi semakin luas dan mendalam, maka pada jenjang pendidikan SMP/ MTs dan SMA/MA, akan lebih baik bila keterpaduan dibatasi pada mata pelajaran yang termasuk bidang kajian sains saja. Hal ini dimaksudkan agar tidak terlalu banyak

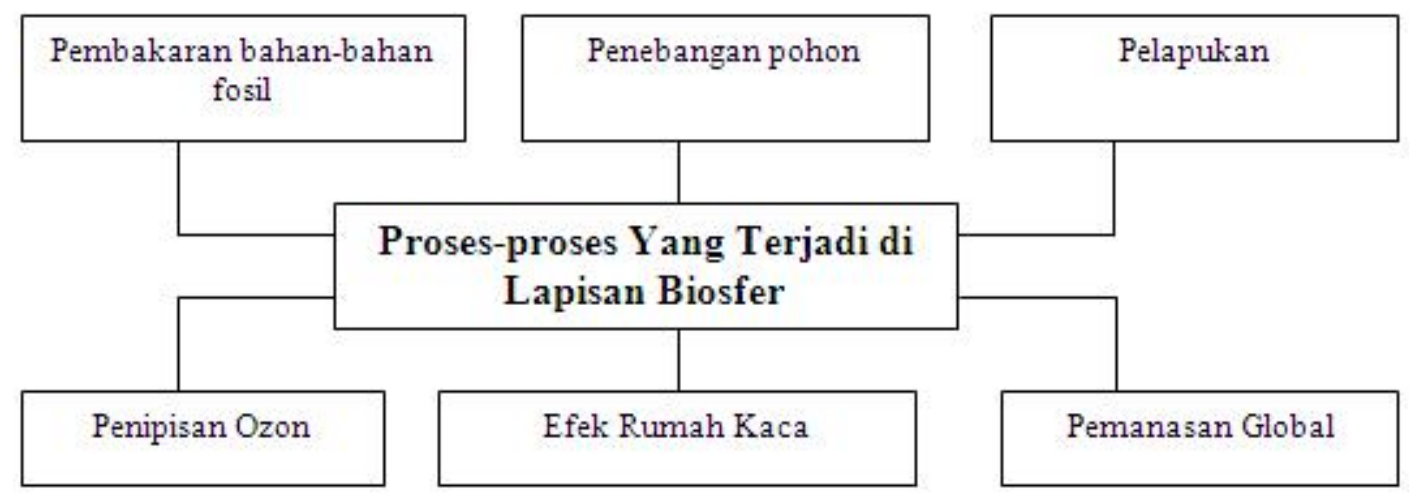

\section{Gambar 2. Jaringan Tema Proses-proses Yang Terjadi di Lapisan Biosfer}

mengurangi kelemahan-kelemahan di atas, perlu dibahas bersama oleh guru mata pelajaran terkait dengan sikap terbuka. Kesemuanya ini ditujukan untuk meningkatkan efektivitas dan efisiensi dalam pembelajaran sains.

\subsubsection{Pemaduan Konsep Dalam Pembelajaran Sains}

Salah satu kunci pembelajaran terpadu yang terdiri atas beberapa mata pelajaran adalah menyediakan lingkungan belajar yang menempatkan peserta didik mendapat pengalaman belajar yang dapat menghubung-kaitkan guru yang terlibat, yang akan membuka peluang timbulnya kesulitan dalam pembelajaran dan penilaian.

Pembelajaran terpadu diawali dengan penentuan tema, karena penentuan tema akan membantu peserta didik dalam beberapa aspek yaitu:

1. peserta didik yang bekerja sama dengan kelompoknya akan lebih bertanggung jawab, berdisiplin, dan mandiri;

2. peserta didik menjadi lebih percaya diri dan termotivasi dalam belajar bila mereka berhasil menerapkan apa yang telah dipelajarinya; 
J. Pijar MIPA, Vol. III No.1, Maret 2008 : 23 - 29.

ISSN 1907-1744

3. peserta didik lebih memahami dan lebih mudah mengingat karena mereka 'mendengar', 'berbicara', 'membaca', 'menulis' dan 'melakukan' kegiatan menyelidiki masalah yang sedang dipelajarinya;

4. memperkuat kemampuan berbahasa peserta didik;

5. belajar akan lebih baik bila peserta didik terlibat secara aktif melalui tugas proyek, kolaborasi, dan berinteraksi dengan teman, guru, dan dunia nyata.

Oleh karena itu, jika guru hendak melakukan pembelajaran terpadu dalam sains, sebaiknya perlu memilih tema yang menghubungkan antara sains-lingkunganteknologi-masyarakat. Jaringan tema yang dapat dipadukan dalam pembelajara terlihat pada Gambar 1 dan 2.

\subsection{Perencanaan Pembelajaran Sains Terpadu}

Keberhasilan pembelajaran terpadu akan lebih optimal jika perencanaan mempertimbangkan kondisi dan potensi peserta didik (minat, bakat, kebutuhan, dan kemampuan). Standar kompetensi dan kompetensi dasar yang harus dimiliki peserta didik sudah tercantum dalam Standar Kompetensi dan Kompetensi Dasar per submata pelajaran sains. Ada berbagai model dalam mengembangkan pembelajaran sains Terpadu, dan salah satunya dapat dilihat pada alur penyusunan perencanaan pembelajaran terpadu seperti pada Gambar 3.
Langkah (2):

Mempelajari standar kompetensi dan kompetensi dasar dari mata pelajaran yang akan dipadukan. Pada tahap ini dilakukan pengkajian atas kompetensi dasar pada semester dan kelas yang sama, antarsemester pada kelas yang sama, antarsemester dan kelas yang berbeda dari beberapa submata pelajaran sains yang memungkinkan untuk diajarkan secara terpadu.

Langkah (3):

Memilih dan menetapkan tema atau topik pemersatu. Memilih tema/topik dapat dirumuskan dengan melihat isuisu yang terkini, misalnya penyakit demam berdarah, HIV/ AIDS, dan lainnya, kemudian baru dilihat koneksitasnya dengan kompetensi dasar dari berbagai sub mata pelajaran sains.

Langkah (4):

Membuat matriks keterhubungan kompetensi dasar dan tema/topik pemersatu. Tujuannya adalah untuk menunjukkan kaitan antara tema/topik dengan kompetensi dasar yang dapat dipadukan.

Langkah (5):

Menyusun dan merumuskan indikator pencapaian hasil belajar untuk setiap kompetensi dasar dari sub mata pelajaran yang dipadukan.

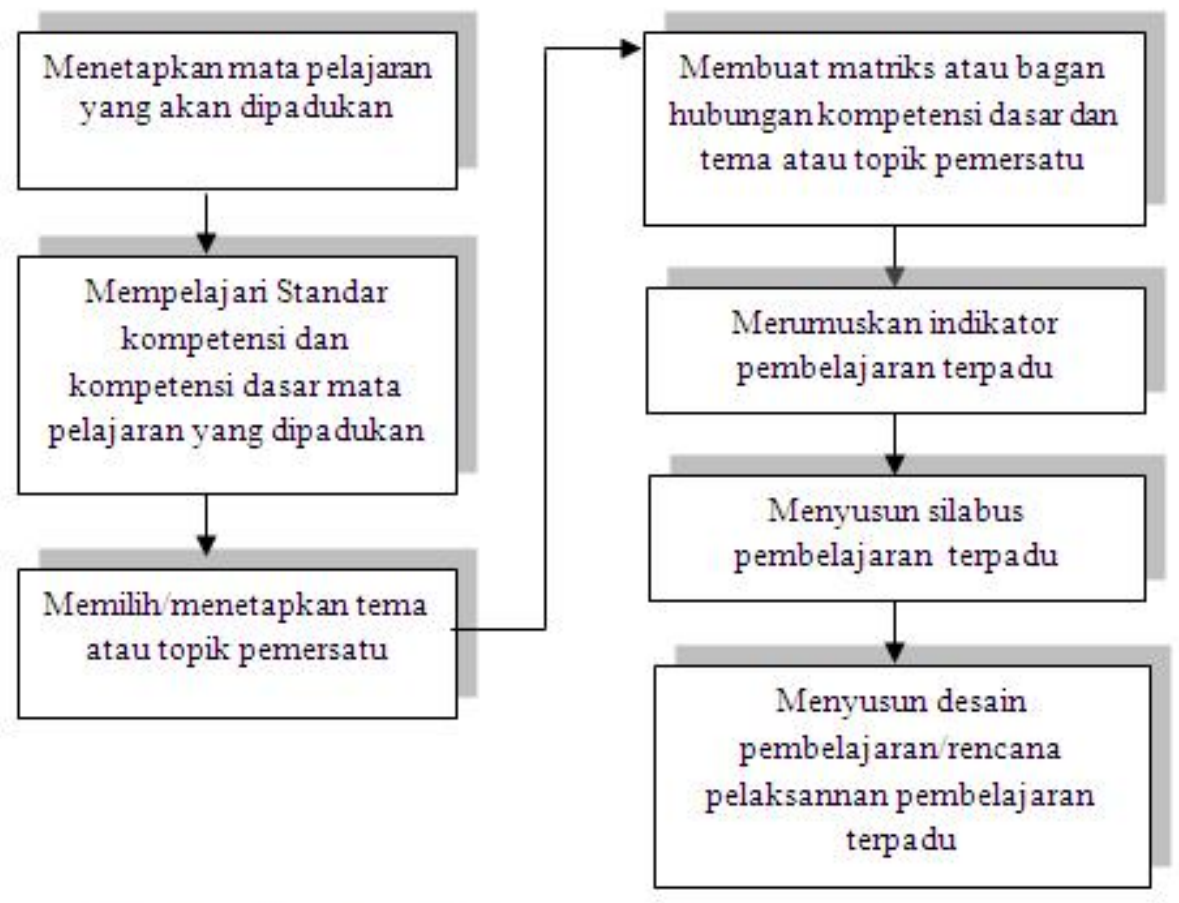

\section{Gambar 3. Alur penyusunan perencanaan pembelajaran terpadu}

Langkah (1):

Menetapkan mata pelajaran yang akan dipadukan. Pada saat menetapkan beberapa mata pelajaran yang akan diadukan sebaiknya sudah disertai dengan alasan atau rasional yang berkaitan dengan pencapaian standar kompetensi dan kompetensi dasar oleh peserta didik dan kebermaknaan belajar.
Langkah (6):

Menyusun silabus pembelajaran sains terpadu, dikembangkan dari berbagai indikator sub mata pelajaran sains menjadi beberapa pengalaman belajar yang konsep keterpaduan atau keterkaitannya menyatu antara beberapa submata pelajaran sains.

Langkah (7): 
Menjabarkan silabus menjadi desain pembelajaran atau rencana pelaksanaan pembelajaran untuk setiap pertemuan.

\subsection{Desain Pelaksanaan Pembelajaran}

Model pembelajaran dalam hal ini adalah menjabarkan silabus menjadi desain pembelajaran/rencana pelaksanaan pembelajaran terpadu, dikemas dalam kegiatan pendahuluan, kegiatan inti, dan kegiatan penutup/tindak lanjut.

\subsubsection{Kegiatan Awal/Pendahuluan}

Kegiatan pendahuluan merupakan kegiatan awal yang harus ditempuh guru dan peserta didik pada setiap kali pelaksanaan pembelajaran terpadu. Fungsinya adalah untuk menciptakan suasana awal pembelajaran yang efektif, yang memungkinkan peserta didik dapat mengikuti proses pembelajaran dengan baik. Efisiensi waktu dalam kegiatan awal ini perlu diperhatikan, karena waktu yang tersedia relatif singkat yaitu antara 5-10 menit. Dengan waktu yang relatif singkat tersebut, diharapkan guru dapat menciptakan kondisi awal pembelajaran dengan baik sehingga peserta didik siap mengikuti pembelajaran dengan seksama.

Langkah-langkah dalam kegiatan pendahuluan ini terdiri atas beberapa tahap yaitu:

a. menarik perhatian peserta didik untuk menumbuhkan kesiapan belajar;

b. memotivasi peserta didik: membangkitkan semangat dan minat peserta didik untuk siap menerima pelajaran;

c. memberikan acuan topik yang akan dibahas;

d. mengaitkan topik yang akan dipelajari dengan topik yang telah dipelajari yang dapat dilakukan dengan mengajukan pertanyaan tentang topik yang sudah dipelajari sebelumnya dan memberikan komentar atas jawaban peserta didik.

Dalam kegiatan pendahuluan ini guru dapat pula melakukan penilaian awal peserta didik (tes awal) yang dapat diberikan secara lisan maupun tertulis.

\subsubsection{Kegiatan Inti}

Kegiatan inti merupakan kegiatan pelaksanaan pembelajaran terpadu yang menekankan pada proses pembentukan pengalaman belajar peserta didik (learning experience). Pengalaman belajar dapat terjadi melalui kegiatan tatap muka dan kegiatan nontatap muka. Kegiatan tatap muka dimaksudkan sebagai kegiatan pembelajaran, peserta didik dapat berinteraksi langsung dengan guru maupun dengan peserta didik lainnya. Kegiatan nontatap muka dimaksudkan sebagai kegiatan pembelajaran yang dilakukan peserta didik dengan sumber belajar lain di luar kelas atau di luar sekolah.

Kegiatan inti pembelajaran terpadu bersifat situasional, yakni disesuaikan dengan situasi dan kondisi setempat. Terdapat beberapa kegiatan yang dapat dilakukan dalam kegiatan inti pembelajaran terpadu, di antaranya adalah sebagai berikut ini:

a. Kegiatan yang paling awal: Guru memberitahukan tujuan atau kompetensi dasar yang harus dicapai oleh peserta didik beserta garis besar materi yang akan disampaikan. Cara yang paling praktis adalah menuliskannya di papan tulis dengan penjelasan secara lisan mengenai pentingnya kompetensi tersebut yang akan dikuasai oleh peserta didik.

b. Alternatif kegiatan belajar yang akan dialami peserta didik. Guru menyampaikan kepada peserta didik kegiatan belajar yang harus ditempuh peserta didik dalam mempelajari tema atau topik yang telah ditentukan. Kegiatan belajar hendaknya lebih mengutamakan aktivitas peserta didik, atau berorientasi pada aktivitas peserta didik. Guru hanya sebagai fasilitator yng memberikan kemudahan kepada peserta didik untuk belajar. Peserta didik diarahkan untuk menemukan sendiri apa yang dipelajarinya. Prinsip belajar sesuai dengan 'konstruktivisme' hendaknya dilaksanakan dalam pembelajaran terpadu

Dalam membahas dan menyajikan materi/bahan ajar terpadu harus diarahkan pada suatu proses perubahan tingkah laku peserta didik, penyajian harus dilakukan secara terpadu melalui penghubungan konsep di mata pelajaran yang satu dengan konsep di mata pelajaran lainnya. Guru harus berupaya untuk menyajikan bahan ajar dengan strategi mengajar yang bervariasi, yang mendorong peserta didik pada upaya penemuan pengetahuan baru, melalui pembelajaran yang bersifat klasikal, kelompok, dan perorangan.

\subsubsection{Kegiatan Akhir/Penutup dan tindak lanjut}

Waktu yang tersedia untuk kegiatan penutup atau kegiatan akhir pembelajaran terpadu ini cukup singkat. Oleh karena itu guru perlu mengatur dan memanfaatkan waktu seefisien mungkin. Secara umum kegiatan penutup ini terdiri atas hal-hal sebagai berikut ini.

a. Mengajak peserta didik untuk menyimpulkan materi yang telah diajarkan.

b. Melaksanakan tindak lanjut pembelajaran dengan pemberian tugas atau latihan yang harus dikerjakan di rumah, menjelaskan kembali bahan yang dianggap sulit oleh peserta didik, membaca materi pelajaran tertentu, memberikan motivasi atau bimbingan belajar.

c.Mengemukakan topik yang akan dibahas pada pertemuan selanjutnya.

d. Memberikan evaluasi lisan atau tertulis.

\subsection{Penilaian Dalam Pembelajaran Terpadu}

Model penilaian yang dikembangkan mencakup prosedur yang digunakan, jenis dan bentuk penilaian, serta alat evaluasi yang digunakan. Model penilaian ini disesuaikan dengan penilaian berbasis kelas pada Standar Kompetensi dan Kompetensi Dasar. Objek penilaian mencakup penilaian terhadap proses dan hasil belajar peserta didik.

Hasil belajar pada hakikatnya merupakan kompetensikompetensi yang mencakup aspek pengetahuan, keterampilan, sikap dan nilai-nilai yang diwujudkan dalam kebiasaan berpikir dan bertindak. Kompetensi dapat diukur melalui sejumlah hasil belajar yang indikatornya dapat diukur dan diamati. Penilaian proses dan hasil belajar saling berkaitan satu dengan yang lainnya karena hasil belajar merupakan akibat dari proses belajar. 
Jenis penilaian terpadu terdiri atas tes dan bukan tes. Sistem penilaian dengan menggunakan tes merupakan sistem penilaian konvensional. Sistem ini kurang dapat menggambarkan kemampuan peserta didik secara menyeluruh, sebab hasil belajar digambarkan dalam bentuk angka yang gambaran maknanya sangat abstrak. Oleh karena itu untuk melengkapi gambaran kemajuan belajar secara menyeluruh maka perlu dilengkapi dengan non-tes.

Selanjutnya guru dapat melaksanakan beberapa teknik penilaian, baik yang termasuk dalam ranah kognitif, afektif, maupun psikomotor. Tugas berupa laporan baik secara individu maupun kelompok sebaiknya disusun berupa tugas aplikasi, misalnya merupakan hasil pengamatan di luar kelas. Dapat pula berupa tugas sintesis dan evaluasi, misalnya tugas pemecahan masalah lingkungan dan usulan cara penanggulangannya. Melalui penugasan ini maka kemampuan berpikir dan kepekaan peserta didik akan dapat terasah.

\section{KESIMPULANDAN SARAN}

Sesuatu yang baru atau merupakan inovasi tentu tidak mudah untuk dilaksanakan, karena memerlukan penyesuaian diri dan kemauan untuk beradaptasi. Begitu pula halnya dengan pembelajaran sains Terpadu. Pembelajaran terpadu biasa dilakukan pada jenjang pendidikan usia dini, namun tidak menutup kemungkinan untuk diterapkan di jenjang pendidikan yang lebih tinggi, yaitu jenjang SMP/MTs dan SMA/MA. Hasil uji coba menunjukkan bahwa pembelajaran terpadu dapat dilaksanakan.

Dalam pelaksanaannya, pembelajaran dapat dilakukan oleh tim pengajar atau guru tunggal. Hal ini tergantung pada kondisi sekolah. Bila di suatu sekolah guru sains terdiri atas guru fisika, kimia, biologi, maka dalam penyusunan silabus, perencanaan pembelajaran, penggunaan media, dan strategi mengajar sebaiknya dibuat bersama hingga penyusunan alat penilaiannya. Namun dalam pembelajarannya dapat dilakukan oleh guru tunggal. Bila di sekolah, seorang guru mengajar semua mata pelajaran sains, dan mengalami kesulitan untuk memadukan kompetensi dasar, indikator, dan materi, maka sangat dianjurkan agar guru tersebut bekerja sama dalam kelompok MGMP agar dapat terjadi diskusi tentang perencanaan strategi dan pelaksanaan KBM. Indikator yang sudah dipadukan tidak perlu diajarkan dua kali karena tujuan pembelajaran terpadu adalah efisiensi dan efektivitas dalam pembelajaran.

Dalam pelaksanaan pembelajaran terpadu penting adanya kerja sama antarguru sains yang ada di suatu sekolah dalam membuat perencanaan pembelajaran, mulai dari silabus, desain pembelajaran/rencana pelaksanaan pembelajaran hingga kesepakatan dalam bentuk penilaian. Bila hal ini dapat dilaksanakan, maka pembelajaran terpadu dapat meningkatkan kerja sama antarguru sains, baik yang ada di sekolah maupun dalam lingkup MGMP.

Bagi peserta didik, pembelajaran terpadu dapat mempertajam kemampuan analitis terhadap konsep-konsep yang dipadukan, karena dapat mengembangkan kemampuan asosiasi konsep dan aplikasi konsep. Pembelajaran terpadu perlu dilakukan dengan variasi metode yang tidak membosankan. Aktivitas pembelajaran harus lebih banyak berpusat pada peserta didik agar dapat mengembangkan berbagai potensi yang dimilikinya.

Bahan ajar yang digunakan tidak hanya buku mata pelajaran saja, tetapi dapat dari berbagai mata pelajaran yang direkatkan oleh tema. Peserta didik dapat juga mencari berbagai sumber belajar lainnya. Bahkan bila memungkinkan mereka dapat menggunakan teknologi informasi yang ada. Aktivitas peserta didik dalam penugasan dapat menjadi nilai tambah yang menguntungkan.

Dalam pembelajaran terpadu diperlukan berbagai alat dan media pembelajaran. Karena digunakan untuk pembelajaran konsep yang direkatkan oleh tema, maka penggunaan sarana pembelajaran dapat lebih efisien jika dibandingkan dengan pemisahan mata pelajaran. Memang tidak semua konsep dapat dipadukan. Konsep-konsep yang dipilih untuk direkat oleh tema dapat menghemat waktu dan ruang.

\section{DAFTAR PUSTAKA}

[1] Druxes H., Born G., Siemsen F. 1983. Kompedium Didaktik Physiks. Munchen: Ehrenwirth Verlag GmBH \& co. KG.

[2] Fogarty, Robin. 1991. How to Integrated the Curricula. Illionis: IRI/Skylight Publishing. Inc.

[3] Hadisubroto, T. 1998. Pembelajaran Terpadu: Materi Pokok PGSD. Jakarta: Universitas Terbuka.

[4] Prabowo. 2002. Pembelajaran Fisika dengan Pendekatan Terpadu dalam Menghadapi Perkembangan IPTEK Milenium III. Makalah disampaikan pada Seminar dan Lokakarya Jurusan Fisika FMIPA UNESA bekerjasama dengan Himpunan Fisika Indonesia (HFI) dengan tema Optimalisasi Peranan Fisika Menghadapi Perkembangan IPTEK Millenium III pada tanggal 10 Pebruari. Surabaya: Unesa.

[5] Sa'ud, Udin Syaefudin., Ade Rukmana, dan Novi Resmini. 2006. Pembelajaran Terpadu. Bandung: UPI Press.

[6] Sismanto. 2007. Menakar Integrasi IPA dalam Kurikulum Tingkat Satuan Pendidikan (KTSP). Akses tanggal 13 September 2007: mkpd.wordpress.com/2007/05/21/ menakar-integrasi-ipa-dalam-kurikulum-tingkatsatuan-pendidikan-ktsp/ - 20k- 